\title{
Effectiveness of Olive Oil with Virgin Coconut Oil on Pruritus Grade Scores Among Hemodialysis Patients
}

\author{
Rizki Muliani ${ }^{1 *}$, Vina Vitniawati ${ }^{2}$, Denden Ardiyana Rakhman ${ }^{3}$ \\ 1,2 Bhakti Kencana University, Bandung, Indonesia \\ ${ }^{3}$ Majalaya Regional Public Hospital Bandung District, Bandung, Indonesia \\ ${ }^{*}$ Correspondence E-mail : rizki.muliani@bku.ac.id
}

\begin{abstract}
Hemodialysis is an action taken to treat various problems caused by Chronic Kidney Disease (CKD). Pruritus is a complication that often occurs due to hemodialysis. This can cause injury to the skin and interfere with patient comfort. Emollients are recommended to treat pruritus. Virgin Coconut Oil (VCO) and Olive Oil $(\mathrm{OO})$ are effective emollients to treat pruritus because they are easy to obtain, natural, and without side effects. The purpose of this study was to assess differences in the effectiveness of reducing pruritus grade scores in hemodialysis patients using VCO and OO. This study used a quasiexperiment with two groups pre-posttest design. Samples were taken using the purposive sampling technique involving 72 patients undergoing hemodialysis which were divided into two groups (VCO and $\mathrm{OO}$ ). The instrument used was the score of the degree of pruritus and the data were analyzed by the Mann-Whitney test. The results of the study obtained a $p$-value of $0.008(<0.05)$ which means that there is a difference in the effectiveness of giving $\mathrm{VCO}$ with $\mathrm{OO}$ on the score of the degree of pruritus in patients. It was found that VCO is more effective in reducing the score of the degree of pruritus in patients. So, the nurses can use VCO as an alternative intervention in the treatment of pruritus in hemodialysis patients.
\end{abstract}

Keywords: Chronic Kidney Disease, Hemodialysis, Olive Oil, Pruritus, Virgin Coconut Oil

\section{Introduction}

Kidneys are organs that are very important in the regulation of acid-base fluids, metabolism, removal of toxins and waste from the body. However due to some kind of damage the kidneys fail to carry out their functions, and if left unchecked, chronic kidney disease (CKD) can occur. Then the kidneys are unable to maintain metabolism and fluid-electrolyte balance, resulting in uremia (Sarastika et al., 2019). This build-up of uremia can be treated by dialysis, where hemodialysis is the main choice because it is effective in increasing the life span of the patients from 5 years to 20 years and is a common treatment method for patients with chronic kidney disease (Saran et al., 2017).

The number of Hemodialysis procedures in Indonesia in 2018 increased by 2,754,409 from 1,694,432 in 2017, the province of West Java had a fairly large contribution with 33,828 active patients and 14,771 new patients. The duration of hemodialysis ranges from 3-4 hours per session, which has an impact on the quality of life itself because time determines the adequacy of therapy. Insufficient doses of targeted hemodialysis will cause various complications which include hypotension, air 
embolism, chest pain, nausea and vomiting, painful muscle cramps, increased levels of uremia, and pruritus (Juwita et al., 2017).

Uremic pruritus is a common complication experienced by almost $40-70 \%$ of hemodialysis patients (Rehman et al., 2018). Research on pruritus are very rare compared to studies of other hemodialysis complications such as fatigue. Dry skin is the main factor that causes pruritus in hemodialysis patients (Ozen et al., 2018), which occurs due to fluid withdrawal during hemodialysis, accumulation of beta 2 microglobulin levels in the blood, and retention of vitamin A (Melastuti et al., 2016). Severe pruritus can cause characteristic linear xerosis of the skin accompanied by bleeding and infection, also causes activity disturbances, disrupts sleep, and reduces the quality of life (Pardede, 2016).

Pruritus in hemodialysis patients is a problem that must not be ignored and requires serious treatment because it will get worse with the ongoing hemodialysis process along with the loss of fluid from the patient's body. Therefore, it is necessary to treat pruritus in CKD patients. To reduce pruritus complaints, GLAEnriched cream can be used, optimizing the dose of dialysis, topical capsaicin, and emollients (Simonsen et al., 2017). Emollient is a material used to prevent or reduce dryness as a protection for the skin. It works by filling the keratinocyte space to form a smooth surface by using an oily and waterinsoluble material and increasing the cohesion of the keratinocyte cells. Emollient ingredients help improve the water barrier function in areas of the skin where natural lipids are lost or damaged and also have the same effect as the natural lipid bilayer of the skin which functions to prevent evaporation of water from the skin's surface. There are several types of emollients including Castrol oil, polyglycerol-3 diisostrearate, di-octyladipate, PPG-15 stearyl ether, glycerol tri (2-ethyl hexanoate), olive oil, virgin coconut oil (VCO) (Noor et al., 2013).

To overcome pruritus in CKD patients, research is mostly carried out using chemicaltype topical drugs. In a previous study, it was suggested to treat pruritus using emollients (Shirazian et al., 2017). In Simonsen et al., (2017) systematic review stated that topical emollient treatments can be used in patients with uremic pruritus. The use of olive oil topical therapy specifically in pruritic patients with CKD is still rarely found in research, especially in Indonesia. So in this study, researchers used VCO and Olive Oil as emollients because they were easy to obtain in Indonesians.

VCO is coconut oil that is not hydrogenated so that its anti-oxidant components are not damaged and are free from trans fats. VCO can also act as an emollient and as an occlusive agent if applied at the right concentration (Noor et al., 2013), It is a natural skin moisturizer because it can prevent tissue damage and provide protection to the skin. Giving VCO is more effective than for CKD patients undergoing hemodialysis to reduce the severity of pruritus because VCO has a higher lipid content than lotion. The lipid can soften the skin and the uric acid in coconut oil is antibacterial and antifungal that helps the body fight infection (Melastuti et al., 2016). In other studies also mention olive oil can affect the scale of pruritus. This oil contains the highest good fats compared to other types of oils that are capable of moisturizing and plumping the skin with a combination of vitamins $A$ and $E$. The content of fatty acids (especially uric acid and oleic acid) in this VCO will soften the skin. In addition, the uric acid content in coconut oil has antibacterial and antifungal properties that help the body fight infection. Therefore, VCO is effective and safe to use as a moisturizer on the skin because it can increase skin hydration, and accelerate skin healing (Melastuti et al., 2016).

Olive oil comes from the fruit of the Olea europaea tree which consists of oleic acid, sterols, carotenoids, triterpenic alcohols, and phenolic compounds. The phenolic content has higher antioxidant properties than vitamin $\mathrm{E}$ and also has anti-inflammatory properties (Lin et al., 2018). So, olive oil has an important role for health and has the benefit of preventing skin irritation, and can also keep the skin smooth and soft (Mondal et al., 2014). In addition, olive oil contains vitamin $\mathrm{C}$ which can produce collagen which is beneficial for the skin because it forms a naturally moist layer. Olive oil also contains vitamins $E$ and $K$ which function as nutrients for the skin. Along 
with these it contains monounsaturated fats, glycerides, moisturizers, and anti-aging properties which are very beneficial for skin health (Ariyani et al., 2020).

This study is a continuation of previous studies that suggested the use of emollients for the treatment of pruritus. With many benefits for the skin and easily availability, VCO and olive oil were selected from several types of emollients used for research on pruritus experienced by CKD patients. Therefore, this study aimed to assess the differences in the effectiveness of VCO with olive oil in treating pruritus in patients undergoing hemodialysis.

\section{Materials and Method}

This research is a quasi-experimental research with two groups pre-post-test design to see the effectiveness of VCO with Olive oil on pruritus. The population in this study was 168 CKD patients in the hemodialysis room at Majalaya Regional Public Hospital. The sample in this study was taken using a purposive sampling technique based on the inclusion criteria: CKD patients with pruritus undergoing scheduled hemodialysis regularly, and has undergone hemodialysis for at least 6 months. The sample in this study was 36 people for the VCO group and 36 people for the Olive oil group. The research instrument used was Duo's grade of pruritus, which was taken from the system proposed by Duo (1987), modified by Mettang \& Setyaningrum, (2016)and again by Hiroshige et al., (1995) to measure the score of pruritus degree and the working procedure VCO and olive oil application.

Data were collected by measuring the score of pruritus grade in both groups. Then group 1 was given VCO and group 2 was given olive oil according to a predetermined procedure after that hemodialysis was carried out. Researchers teach patients regarding the use of VCO and olive oil. The provision of VCO and olive oil is done twice a day $(09.00 \mathrm{am}$ and $7.00 \mathrm{pm}$ ), for the second use, the researcher recommends the patient to do it at home. To monitor and prevent bias, the researcher made a contract with the patient's family as a reminder and supervisor of the patient in applying VCO and olive oil at home. In addition, the researcher also communicated with the family to reminder about the therapy. The provision of VCO and olive oil was carried out for 2 weeks with documentation of the pruritus degree score assessment carried out every week. After one week of completion of each therapy, then on the second week, a post-test was carried out by measuring the score of pruritus grade. Data were analyzed using the Mann-Whitney test.

This research has been approved by the Health Research Ethics Commission of Majalaya Regional Public Hospital Bandung DistrictNumber:070/60/K.ETIK PENELITIAN dated $15^{\text {th }}$ March 2021.

\section{Results}

From table 1 , it can be seen that patients undergoing hemodialysis before being given olive oil, almost all (83.33\%) were on a score of pruritus grade 2 (itching and scratching without excoriation), and most of them $(52.78 \%)$ were on a score of pruritus grade 3 (itching with continuous scratching or with excoriation) before being given VCO.

Table 1 Pruritus grade scores before being given Olive oil and VCO among Hemodialysis Patients $(n=36)$

\begin{tabular}{|c|c|c|c|c|c|c|}
\hline \multirow{2}{*}{$\begin{array}{c}\text { Pruritus } \\
\text { grade scores }\end{array}$} & \multicolumn{3}{|c|}{ Olive Oil Group } & \multicolumn{3}{|c|}{ VCO Group } \\
\hline & $\mathrm{F}$ & $\%$ & Median & $\mathrm{F}$ & $\%$ & Median \\
\hline 1 & 1 & 2.78 & & 0 & 0 & \\
\hline 2 & 30 & 83.33 & 2 & 13 & 36.11 & 3 \\
\hline 3 & 5 & 13.89 & & 19 & 52.78 & \\
\hline 4 & 0 & 0 & & 4 & 11.11 & \\
\hline Total & 36 & 100 & & 36 & 100 & \\
\hline
\end{tabular}


Int J Adv Life Sci Res. Volume 4(4)25-33

Table2: Pruritus grade scores after being given Olive oil and VCO among Hemodialysis Patients $(n=36)$

\begin{tabular}{|c|c|c|c|c|c|c|c|c|c|c|c|c|}
\hline \multirow{3}{*}{$\begin{array}{c}\text { Pruritus } \\
\text { grade } \\
\text { scores }\end{array}$} & \multicolumn{6}{|c|}{ Olive Oil Group } & \multicolumn{6}{|c|}{ VCO Group } \\
\hline & \multicolumn{3}{|c|}{ Post-test Week I } & \multicolumn{3}{|c|}{ Post-test Week II } & \multicolumn{3}{|c|}{ Post-test Week I } & \multicolumn{3}{|c|}{ Post-test Week II } \\
\hline & $\mathrm{F}$ & $\%$ & Median & $\mathrm{F}$ & $\%$ & Median & $\mathrm{F}$ & $\%$ & Median & $\mathrm{F}$ & $\%$ & Median \\
\hline 1 & 6 & 16.67 & 2 & 27 & 75 & 1 & 4 & 11.11 & 2 & 19 & 52.78 & 1 \\
\hline 2 & 29 & 80.56 & & 9 & 25 & & 29 & 80.56 & & 17 & 47.72 & \\
\hline 3 & 1 & 2.78 & & 0 & 0 & & 3 & 8.33 & & 0 & & \\
\hline 4 & 0 & 0 & & 0 & 0 & & 0 & 0 & & 0 & & \\
\hline Total & 36 & 100 & & 36 & 100 & & 36 & 100 & & 36 & 100 & \\
\hline
\end{tabular}

Table3: Effect of Olive Oil and VCO on Pruritus Grade Scores among Hemodialysis Patients $(n=36)$

\begin{tabular}{ccccc}
\hline & \multicolumn{2}{c}{ Olive oil } & \multicolumn{2}{c}{ VCO } \\
\cline { 2 - 4 } Measurement & Median (min-max) & p-value & Median (min-max) & $p$-value \\
\hline Pre-test & $2(1-3)$ & & $3(2-4)$ & \\
Post-test week I & $2(1-3)$ & 0.003 & $2(1-3)$ & 0.000 \\
Post-test week II & $1(1-2)$ & 0.000 & $1(1-2)$ & 0.000 \\
\hline
\end{tabular}

Based on table 2, it can be seen that patients undergoing hemodialysis after being given olive oil, almost all $(80.56 \%)$ remained on a score of pruritus grade 2 (itching with scratching without excoriation) in the first week and most (75\%) were on a score of pruritus grade 1 (itching without scratching) at second week. After being given VCO, almost all $(80.56 \%)$ were on a score of pruritus grade 2 (itching with scratching without excoriation) in the first week and most (52.78\%) were on a score of pruritus grade 1 (itching without scratching) in the second week.

It can be seen in table 3 that there is an effect of giving olive oil and VCO on the score of pruritus grade in patients undergoing hemodialysis.

Table4: Effectiveness of Olive Oil and VCO on Pruritus Grade Scores among Hemodialysis Patients $(n=36)$

\begin{tabular}{ccc}
\hline Group & Median & $\begin{array}{c}p- \\
\text { value }\end{array}$ \\
\hline Post-test Olive Oil week I & 2 & 0.000 \\
Post-test VCO week I & 1 & \\
\hline Post-test Olive Oil week II & 1 & 0.008 \\
Post-test VCO week II & 1 & \\
\hline
\end{tabular}

Table 4, shows that there is a difference in the effectiveness of giving olive oil with VCO on the score of pruritus grade in patients undergoing hemodialysis. The score of pruritus grade has not decreased after administration of olive oil in the first week, while the administration of VCO has reduced the score of pruritus grade by 1 in the first week. Therefore, the administration of VCO is more effective in reducing the score of pruritus grade in patients undergoing hemodialysis.

\section{Discussion}

Pruritus is an unpleasant sensation on the skin and causes discomfort that urges the patient to scratch (Harlim \& Yogyartono, 2012; Verduzco \& Shirazian, 2020). Pruritus is defined as itching that occurs at least 3 times within 2 weeks and occurs regularly for more than 6 months (Roswati, 2013). This condition can persist and continue in patients undergoing hemodialysis (Verduzco \& Shirazian, 2020). Pruritus often occurs in hemodialysis patients with an incidence of almost 60-80\% (Takahashi et al., 2018), usually occurs 6 months after dialysis, and usually increases with the length of time the patient is on dialysis (Roswati, 2013). Pruritus in hemodialysis patients occurs due to the accumulation of urea, the effects of pruritogenic substances (histamine, substanceP), increased levels of calcium and phosphorus, skin abnormalities (dry skin) (Harlim \& Yogyartono, 2012; Takahashi et al., 2018).

In this study, it was seen that in both groups of patients who undergoing hemodialysis before being given olive oil and VCO experienced pruritus, whereas in the group before being given olive oil as many as $83.33 \%$ of hemodialysis patients experienced grade 2 
pruritus (itching with scratching without excoriation). It was observed that there were scratch marks on the hands and feet but there were no visible wounds. While the group before being given VCO as much as $52.78 \%$ of hemodialysis patients experienced grade 3 pruritus (itching with continuous scratching or with excoriation), it was proven when observed that there were scratching scars on the hands and feet of respondents. Complaints of pruritus with different skin conditions can be caused by dry skin due to limited water intake due to kidney damage, sebaceous gland atrophy that persists on the skin, and can also be caused by toxic uremia. In line with Ozen et al (2018) that pruritus is a clinical symptom in hemodialysis patients, especially uremia conditions and occurs in $53.4 \%$ of patients undergoing hemodialysis.

In the study, it was found that 5 people experienced grade 3 pruritus (itching with continuous scratching or with excoriation) in the group given olive oil and 4 people experienced grade 4 pruritus (itching causing anxiety) in the group given VCO. This could be due to the fact that all respondents were above 35 years of age in the group given olive oil and VCO. Age can affect the severity of pruritus (Nadarajah et al., 2018), whereas those over 40 years of age will experience more severe pruritus (Fauziah \& Soelistyowati, 2018; Kimata et al., 2014). Following research Raiesifar et al., (2018) stated that there is a relationship between age and skin disorders. This is supported by Fauziah \& Soelistyowati (2018) research which stated that most pruritic patients are aged 41-60 years. This can occur due to unhealthy lifestyles such as consuming fast food, stressful activities, sitting all day in the office, often consuming coffee and energy drinks, and rarely consuming water which is a risk factor for kidney damage. Damage to the kidneys is the main cause of uremic pruritus. In addition, at the age of 41-60 years, there is a decrease in the body's ability to metabolize substances that cause uremic pruritus. In the elderly, dry skin conditions can be found which can cause the incidence and severity of xerosis to be higher and will aggravate pruritus (Bianti, 2016).

Hemodialysis can cause severe pruritus (Fauziah\&Soelistyowati, 2018; Kimata et al.,
2014). Following research of Raiesifar et al., (2018) it was found that there is a significant relationship between the length of time undergoing hemodialysis with itching and dry skin. It is in same line with the research of Wahyuni et al., (2019) which states there is a significant relationship between the length of hemodialysis and pruritus in patients with chronic kidney disease where the longer hemodialysis, the higher the pruritus. Pruritus is associated with progressively impaired kidney function. Another opinion stated that most patients suffer from pruritus after years of hemodialysis, whereas in this study patients experienced pruritus after undergoing hemodialysis for 5-31 months. Patients diagnosed with chronic kidney disease and undergoing hemodialysis suffer from uremic frost which is the most common cause of metabolic pruritus (Lin et al., 2012).

The present study reveal that application of olive oil for 2 weeks decrease the score of pruritus grade to grade 1 (itching without scratching). From the results, it was seen that the patient's skin condition became more moist and smooth and the patient rarely feel the itching. A previous study Sebayang \& Sembiring (2020) showed that there was a decrease in the average diaper rash from $4.46 \%$ before being given olive oil to $2.14 \%$ after being given olive oil to infants and toddlers of $0-36$ months. This is in line with research by Hayati et al., (2020) which proves that there is a decrease in the average damage to skin integrity in type II DM patients from 2.5455 before being given olive oil to 1.1818 after being given olive oil with smearing 8 times in 2 weeks. Other studies also prove that giving olive oil for seven days in the morning and evening on the skin surface can prevent skin damage, maintain skin moisture, improve blood circulation, antiinflammatory, and maintain skin elasticity, to prevent pressure ulcers in stroke patients (Meliza et al., 2020).

It was evident that there is a relationship between the administration of Olive Oil and the score of pruritus grade in patients undergoing hemodialysis with a p-value of 0.000 . Following a previous study Hayati et al., (2020), where it was found that there was an effect of olive oil on damaged skin in type II 
DM patients. It is also supported by research by Meliza et al., (2020) which stated that there is an effect of using olive oil on the prevention of pressure ulcers in stroke patients with a pvalue of 0.05 . Olive oil along with fatty acids also contains more than 200 chemical compounds, including sterols, carotenoids, triterpenic alcohols, and phenolic compounds. The phenolic content has higher antioxidant properties than vitamin $\mathrm{E}$ and also has antiinflammatory properties (Lin et al., 2018). So olive oil has an important role for health and has the benefit of preventing skin irritation, and can also keep the skin smooth and soft (Mondal et al., 2014). Olive oil also contains oleic acid which has the main ingredient that can reduce lipid hydroperoxide levels so that it can increase collagen synthesis or the formation of new skin tissue. In addition, olive oil contains vitamin $\mathrm{C}$ which can produce collagen which is beneficial for the skin because it forms a naturally moist layer, contains vitamins $\mathrm{E}$ and $\mathrm{K}$ which function as nutrients for the skin. Olive oil also contains monounsaturated fats, glycerides, moisturizers, and anti-aging properties which are very beneficial for skin health (Ariyani et al., 2020).

Based on the results of this study, it was seen that in the first week there had been a decrease of 1 score of the degree of pruritus, and in the second week, there was a decrease of 2 scores of the degree of pruritus after being given VCO in patients undergoing hemodialysis, where most of the hemodialysis patients had pruritus on a score of pruritus grade 1 (itching without scratching) at second week. From the observations, it was seen that the patient's skin looked cleaner, moisturized and there were no scratch marks and the patient did not feel any more itching, thus helping the patient by making better sleep quality. This is also supported by Asri \& Zuryati (2018), where patient after giving VCO for seven days, found that the itching experience reduced among respondents, the skin which initially looked dry looked a bit moist and the intensity of the itching felt reduced. This shows that the provision of VCO can reduce and maintain the moisture of the respondent skin.
The present study is in line with research by Saodah et al. (2020) which stated that there was a significant effect on skin moisture in the intervention group before and after VCO application ( $p$-value <0.05). Syaputra et al.,(2017) stated that there was a significant difference in the decrease in itching felt by respondents after VCO with a p-value of 0.001 $(<0.05)$. It is also supported by Asri and Zuryati (2018) research which proves that VCO has a significant effect on reducing the degree of pruritus before and after the intervention.

In addition, the uric acid content in coconut oil has antibacterial and antifungal properties that help the body fight infection (Melastuti et al., 2016). The fatty acids in VCO which are absorbed by the body, are not stored and used as fat such as long-chain fatty acids, thereby reducing itching in the body which can increase skin hydration and dry skin elasticityas well as accelerate skin healing (Melastuti et al., 2016; Noor et al., 2013; Saodah et al., 2020), even VCO has an antiinflammatory effect that increases skin protection (Varma et al., 2019).

According to Saodah et al (2020), VCO is believed to be good for skin health because its content is easily absorbed by the skin and contains vitamin $\mathrm{E}$ and antioxidants so it is good for skin protection. VCO is also an ingredient for topical skin moisturizers that are popularly used in skincare in Southeast Asia. VCO has a high fatty acid content and higher antioxidant activity than ordinary coconut oil. Other research (Noor et al., 2013) found that Virgin Coconut Oil Loaded Solid Lipid Particles (VCO-SLPs)act as moisturizing lotions which is effective in increasing skin moisture and increasing skin elasticity because they contain low biodegradability, biocompatibility, and toxicity and have excellent hydration. There was a $24.8 \%$ increase in skin moisture for lotions with VCO-SLP compared to a $12.7 \%$ increase in skin moisture for lotions without VCO. As VCO is easily available it can reduce the costs incurred for treatment and reduce the side effects of drugs. VCO also has other advantages as it contains medium-chain fatty acids (MCFA) which easily enter the deep layers of the skin and maintain skin elasticity that give suppleness and moisturize dry, rough, and scaly skin (Saodah et al., 2020). 
Olive oil and the oleic acid have a little antibacterial effect, but the hydroxytyrosol in olive oil is an antioxidant and has antifungal activity. In addition, olive oil also has a drawback as it can worsen xerosis and atopic dermatitis because of the saturated and unsaturated fatty acid content that can induce inflammation. The oleic acid in olive oil can increase skin penetration by reducing the conformation of the stratum corneum lipids and induces lipid separation phase. This can cause inflammation through the $\mathrm{N}$-methyl-D-aspartic acid (NMDA) type receptors in keratinocytes. VCO contains high levels of lauric acid, which has been shown to have antimicrobial and anti-inflammatory effects in vitro and in vivo in mice. Several studies have proven the effectiveness of $\mathrm{VCO}$ in treating xerosis and atopic dermatitis. VCO has been shown to have a beneficial effect as a skin protector in infants and adults (Karagounis et al., 2019).

\section{Conclusion}

Based on the result of the treatment it is seen that there is a difference in the effectiveness of

\section{References}

Ariyani, H., Hilmawan, R. G., \& Baharudin, L. S. (2020, June). Effectiveness of Allium Sativum and Olive Oil in Overcoming Pruritus in Kidney Failure Patients at Hemodialysis Unit of Dr. Soekardjo Hospital, Tasikmalaya City. In 2nd Bakti Tunas Husada-Health Science International Conference (BTH-HSIC 2019) (pp. 146-148). Atlantis Press.https://doi.org/10.2991/ahsr.k.200523.036

Asri, N. F. S \& Zuryati, M. (2018). Pengaruh Pemberian Terapi VCO (Virgin Coconut Oil) terhadap Pruritus pada Klien Gagal Ginjal Kronik dengan Hemodialisis di RSIJ Cempaka Putih Tahun 2018. Academia Edu, 1- 14.

Bianti, M. (2016). Kulit Kering pada Usia Lanjut. Cermin Dunia Kedokteran, 43(10), 737-740.

Duo, L. J. (1987). Electrical needle therapy of uremic pruritus. Nephron, 47(3), 179-183.

Fauziah, N., \& Soelistyowati, E. (2018). Faktor yang Mempengaruhi Terjadinya Pruritus pada Klien Gagal Ginjal Kronik yang Menjalani Hemodialisis di Rumah Sakit Islam Jemursari Surabaya. Jurnal Keperawatan, Vol. XI No, 111-118.

Harlim, A., \& Yogyartono, P. (2012). Uremic Pruritus in Chronic Kidney Disease. Majalah Kedokteran FK UKI, XXVIII(2), 100-111. olive oil with VCO on the score of the degree of pruritus in patients undergoing hemodialysis. It was found that administration of VCO is more effective in reducing the score of the degree of pruritus in patients undergoing hemodialysis. Nurses can apply VCO as an alternative intervention in the treatment of pruritus in hemodialysis patients. Thus VCO can effectively improve skin moisture and can be used as a nonpharmacological therapy option to improve skin moisture. Furthermore VCO is easy to obtain, cheap and easy to handle.

\section{Acknowledgments}

We wish to thank the management of Bhakti Kencana University and Majalaya Regional Public Hospital Bandung, Indonesia for the permission and support to give necessary permission to carry over the research study.

\section{Conflicts of Interest}

The authors declare no conflict of interest.

Hayati, K., Mutiara, H. S., Agustina, D., Manalu, T. A., \& Sitepu, K. (2020). Pengaruh Minyak Zaitun (Olive Oil) Terhadap Kerusakan Integritas Kulit Pada Pasien Dm Tipe li Di Kecamatan Pagar Merbau. Jurnal Keperawatan Dan Fisioterapi (Jkf), 3(1), 6-12. https://doi.org/10.35451/jkf.v3i1.455

Juwita, L., Febrita, L., \& Putri, Y. R. (2017). Efektivitas Latihan Fisik Intra Dialisis Terhadap Kadar Kreatinin Pasien Hemodialisa. Journal Human Care, 1(1).

Karagounis, T. K., Gittler, J. K., Rotemberg, V., \& Morel, K. D. (2019). Use of "natural" oils for moisturization: Review of olive, coconut, and sunflower seed oil. Pediatric Dermatology, 36(1), 915. https://doi.org/10.1111/pde.13621

Kimata, N., Fuller, D. S., Saito, A., Akizawa, T., Fukuhara, S., Pisoni, R. L., Robinson, B. M., \& Akiba, T. (2014). Pruritus in hemodialysis patients: Results from the Japanese Dialysis Outcomes and Practice Patterns Study (JDOPPS). Hemodialysis International, 18(3), 657-667. https://doi.org/10.1111/hdi.12158

Lin, T. C., Lai, Y. H., Guo, S. E., Liu, C. F., Tsai, J. C., Guo, H. R., \& Hsu, H. T. (2012). Baby oil therapy for uremic pruritus in haemodialysis patients. Journal of Clinical Nursing, 21(1-2), 139- 
$148 . \quad$ https://doi.org/10.1111/j.13652702.2011.03906.x

Lin, T. K., Zhong, L., \& Santiago, J. L. (2018). Antiinflammatory and skin barrier repair effects of topical application of some plant oils. International Journal of Molecular Sciences, 19(1). https://doi.org/10.3390/ijms19010070

Melastuti, Erna \& Setyaningrum, D. A. (2016). Effectiveness of providing Virgin Coconut Oil (VCO) towards pruritus reduction: Study on patients with chronic kidney disease undergoing hemodialysis. The Proceeding of the 7th International Nursing Conference Faculty of Nursing Universitas Airlangga, 281-285.

Mettang, T., Fritz, P., Weber, J., Machleidt, C., Hübel, E., \& Kuhlmann, U. (1990). Uremic pruritus in patients on hemodialysis or continuous ambulatory peritoneal dialysis (CAPD). The role of plasma histamine and skin mast cells. Clinical nephrology, 34(3), 136-141.

Hiroshige, K., Kabashima, N., Takasugi, M., \& Kuroiwa, A. (1995). Optimal dialysis improves uremic pruritus. American journal of kidney diseases, 25(3), 413-419.

Meliza, S. C., Ritarwa, K., \& Sitohang, N. A. (2020). The Prevention of Ulcers Decubitus with Mobilization and The Usage of Olive Oil on Stroke $\begin{array}{lll}\text { Patients. } & \text { Elkawnie, } & \text { 6(2), }\end{array}$ https://doi.org/10.22373/ekw.v6i2.6925

Nadarajah, S., Astri, I., \& Yahya, Y. F. (2018). Hubungan Karakteristik Klinis Dan Keparahan Pruritus Uremik Pada Pasien Gagal Ginjal Kronik Yang Mendapat Hemodialisis. Majalah Kedokteran Sriwijaya, 50(3), 140-145.

Noor, N. M., Aziz, A. A., Sarmidi, M. R., \& Aziz, R. (2013). The effect of virgin coconut oil loaded solid lipid particles (VCO-SLPs) on skin hydration and skin elasticity. Jurnal Teknologi (Sciences and Engineering), 62(1), 39-43. https://doi.org/10.11113/jt.v62.1248

Ozen, N., Cinar, F. I., Askin, D., \& Mut, D. (2018). Uremic pruritus and associated factors in hemodialysis patients: A multi-center study. Kidney Research and Clinical Practice, 37(2), 138-147. https://doi.org/10.23876/j.krcp.2018.37.2.138

Pardede, S. O. (2016). Pruritus Uremik. Sari Pediatri, 11(5), 348-54. https://doi.org/10.14238/sp11.5.2010.348-54

Raiesifar, Z., Tahery, N., Shirzadegan, R., Baraz, S., Darabiyan, P., \& Raiesifar, A. (2019). Assessment of Skin Manifestations in End-Stage Renal Disease Patients Undergoing Hemodialysis in Shahid Beheshti Hospital of Abadan and Vali-e-
Asr Hospital of Khorramshahr. Jundishapur Journal of Chronic Disease Care, 8(1). :e83381. doi: 10.5812/jjcdc.83381.

Rehman, I. U., Munib, S., Ramadas, A., \& Khan, T. M. (2018). Prevalence of chronic kidney diseaseassociated pruritus, and association with sleep quality among hemodialysis patients in Pakistan. PLOS ONE, 13(11), 1-17. https://doi.org/10.1371/journal.pone.0207758

Roswati, E. (2013). Pruritus pada Pasien Hemodialisis. Cdk, 40(4), 260-264.

Mondal, S. C., Singh, P., Kumar, B., Singh, S. K., Gupta, S. K., \& Verma, A. (2014). Ageing and potential anti-aging phytochemicals: an overview. World Journal of Pharmacy and Pharmaceutical Sciences, 4(1), 426-454.

Saputra, L., Gita, F. A. R. I. S. Z. A., \& Dewi, R. S. (2017). Effect of $12.5 \%$ virgin coconut oil (cocos nucifera) mouthwash on plaque index of fixed prosthetic denture users. Int. J. Appl. Pharm, 9, 4144.

Saodah, S., Budi Putra, I., \& Trisa S, C. (2020). The Effect of Virgin Coconut Oil (VCO) with Lotion On The Skin Moisture among Uremic Patients Undergoing Hemodialysis in Hospital Binjai City, Indonesia. International Journal of Nursing and Health Services (IJNHS), 3(5), 560-568. https://doi.org/10.35654/ijnhs.v3i5.319

Saran, R., Robinson, B., Abbott, K. C., Agodoa, L. Y. C., Albertus, P., Ayanian, J., Balkrishnan, R., Bragg-Gresham, J., Cao, J., Chen, J. L. T., Cope, E., Dharmarajan, S., Dietrich, X., Eckard, A., Eggers, P. W., Gaber, C., Gillen, D., Gipson, D., Gu, H., ... Shahinian, V. (2017). US Renal Data System 2016 Annual Data Report: Epidemiology of Kidney Disease in the United States. American Journal of Kidney Diseases, 69(3), A7-A8. https://doi.org/10.1053/j.ajkd.2016.12.004

Sarastika, Y., Kisan, K., Mendrofa, O., \& Siahaan, J. V. (2019). Faktor-Faktor Yang Mempengaruhi Kualitas Hidup Pasien Gagal Ginjal Kronik (Ggk) Yang Menjalani Terapi Hemodialisa Di Rsu Royal Prima Medan. Jurnal Riset Hesti Medan Akper Kesdam I/BB Medan, 4(1), 53. https://doi.org/10.34008/jurhesti.v4i1.93

Sebayang, S. M., \& Sembiring, E. (2020). Efektivitas Pemberian Minyak Zaitun Terhadap Ruam Popok Pada Balita Usia 0-36 Bulan. Indonesian Trust Health Journal, 3(1), 258-264. https://doi.org/10.37104/ithj.v3i1.44

Shirazian, S., Aina, O., Park, Y., Chowdhury, N., Leger, K., Hou, L., Miyawaki, N., \& Mathur, V. S. (2017). Chronic kidney disease-associated pruritus: Impact on quality of life and current management 
challenges. International Journal of Nephrology and Renovascular Disease, 10, 11-26. https://doi.org/10.2147/IJNRD.S108045

Simonsen, E., Komenda, P., Lerner, B., Askin, N., Bohm, C., Shaw, J., Tangri, N., \& Rigatto, C. (2017). Treatment of Uremic Pruritus: A Systematic Review. American Journal of Kidney Diseases, 70(5), 638-655. https://doi.org/10.1053/j.ajkd.2017.05.018

Takahashi, N., Yoshizawa, T., \& Tsuchiya, S. (2018). Current Status and Treatment Strategies of Hemodialysis-Associated Pruritus. Contributions to Nephrology, 196, 88-95. https://doi.org/10.1159/000485705

Varma, S. R., Sivaprakasam, T. O., Arumugam, I., Dilip, N., Raghuraman, M., Pavan, K. B., Rafiq, M., \& Paramesh, R. (2019). In vitro anti-inflammatory and skin protective properties of Virgin coconut oil. Journal of Traditional and Complementary Medicine, 9(1), 5-14. https://doi.org/10.1016/j.jtcme.2017.06.012
Verduzco, H. A., \& Shirazian, S. (2020). CKDAssociated Pruritus: New Insights Into Diagnosis, Pathogenesis, and Management. Kidney International Reports, 5(9), 1387-1402. https://doi.org/10.1016/j.ekir.2020.04.027

Wahyuni, A., Lawati, U. Z., \& Gusti, E. (2019). Korelasi Lama Menjalani Hemodialisa Dengan Pruritus Pada Pasien Hemodialisa. Jurnal Endurance, $\quad 4(1), \quad 117$. https://doi.org/10.22216/jen.v4i1.3845. 